\title{
FAKTOR YANG MEMENGARUHI KEJADIAN HIPERTENSI PADA LANSIA DI UPT PUSKESMAS SIGUMPAR
}

\author{
Tetty JR Simanjuntak ${ }^{1}$, Zuraidah Nasution ${ }^{2}$, Tri Niswati Utami ${ }^{3}$ \\ 1,2,3 Institusi Kesehatan Helvetia, Medan, Indonesia \\ Email: tettyjrsimanjuntak@gmail.com
}

\begin{abstract}
Abstrak
Menurut American Heart Association atau AHA dalam Kemenkes, Hipertensi merupakan Silent Killer, dengan gejala yang dapat bervariasi pada masing masing individu dan hampir sama dengan gejala penyakit lainnya, Kemudian menurut Riskesdas Sumatera Utara 2018 data penderita hipertensi pada usia 55-64 sebanyak 13.02\%, usia 65-74 tahun sebanyak 18,07\% dan usia 75 tahun keatas sebanyak $16,21 \%$. Jenis penelitian ini menggunakan survei analitik deskriptif dengan rancangan cross sectional. Populasi dalam penelitian ini adalah seluruh lanjut usia ( $\geq 60$ tahun) penderita hipertensi di Wilayah kerja UPT Puskesmas Sigumpar sebanyak 102 orang.sedangkan sampel berjumlah 102 orang dengan cara total sampling. Analisa data dilakukan dengan analisis univariat, bivariat dan multivariat. Berdasarkan hasil uji chi-square diketahui bahwa kejadian hipetensi berpengaruh terhadap riwayat Keluarga, merokok, obesitas, pola makan, aktivitas fisik dan etnis $p=0,000$, artinya ada pengaruh Riwayat Keluarga, merokok, obesitas, pola makan, aktivitas fisik dan etnis terhadap kejadian hipertensi. Dari hasil analisis multivariat diketahui variabel yang paling berpengaruh dalam penelitian ini adalah variabel obesitas dengan nilai OR 83. Kesimpulan dalam penelitian ini adalah obesitas merupakan faktor yang dominan berpengaruh terhadap kejadian hipertensi di UPT Sigumpar. Untuk dapat menekan prevalensi kejadian hipertensi diharapkan kerjasama Dinas Kesehatan, puskesmas dan petugas kesehatan. Disarankan kepada petugas kesehatan diharapkan dapat melakukan penyuluhan cara mengatasi masalah hipertensi
\end{abstract}

Kata Kunci : Hipertensi, Obesitas, Riwayata Keluarga, Pola Makan

\begin{abstract}
According to the American Heart Association or AHA in the Ministry of Health, Hypertension is a Silent Killer, with symptoms that can vary in each individual and are almost the same as symptoms of other diseases. 65-74 years as much as $18.07 \%$ and ages 75 years and over as much as $16.21 \%$. This type of research uses a descriptive analytic survey with a cross sectional design. The population in this study were all elderly people ( $\geq 60$ years) with hypertension in the working area of the UPT Puskesmas Sigumpar as many as 102 people. While the sample amounted to 102 people by total sampling. Data analysis was carried out by univariate, bivariate and multivariate analysis. Based on the results of the chi-square test, it is known that the incidence of hypertension affects family history, smoking, obesity, diet, physical activity and ethnicity $p=0.000$, meaning that there is an effect of family history, smoking, obesity, diet, physical activity and ethnicity on the incidence of hypertension. From the results of multivariate analysis, it is known that the most influential variable in this study is the obesity variable with an OR value of 83. The conclusion in this study is obesity is the dominant factor influencing the incidence of hypertension at UPT Sigumpar. To be able to reduce the prevalence of hypertension, it is hoped that the cooperation of the Health Service, Puskesmas and health workers is expected. It is recommended that health workers are expected to provide counseling on how to overcome the problem of hypertension
\end{abstract}

Keywords : Hypertension, Obesity, Family History, Diet 


\section{Pendahuluan}

Penyakit kardiovaskular menyebabkan sekitar 17 juta kematian per tahun, hampir sepertiga dari total kematian. Dari jumlah tersebut, hipertensi menyumbang untuk 9,4 juta kematian di seluruh dunia setiap tahun. Hipertensi bertanggung jawab untuk setidaknya $45 \%$ kematian akibat penyakit jantung dan 51\% kematian akibat stroke. Persentase penderita hipertensi saat ini paling banyak terdapat di negara berkembang dibandingkan dengan negara maju. Data dari Global Status Report on Noncommunicable Disesases 2010 dari World Health Organization (WHO) menyebutkan, 40\% negara ekonomi berkembang memiliki penderita hipertensi, sedangkan negara maju hanya $35 \%$. Kawasan Afrika memegang posisi puncak penderita hipertensi sebanyak $46 \%$. Kawasan Amerika menempati posisi terakhir sebanyak 35\%. Di kawasan Asia Tenggara, 36\% orang dewasa menderita hipertensi_dan menyebabkan kematian hampir 1,5 juta orang setiap tahun.

Hipertensi adalah sebagai peningkatan tekanan darah sistolik sedikitnya 140 mmhg atau tekanan diastolik sedikitnya $90 \mathrm{mmhg}$ (Pramuji, 2021). Hipertensi atau darah tinggi adalah peningkatan tekanan darah sistolik diatas batas normal yaitu lebih dari 140 mmhg dan diastolik lebih dari $90 \mathrm{mmhg}$ (Risty, 2020). Menurut organisasi kesehatan dunia (WHO), tekanan darah Sistolik dewasa adalah tekanan yang diperoleh pada saat jantung berkontraksi memompakan darah keseluruh tubuh dimana angka normalnya adalah $120 \mathrm{mmhg}$. Sementara tekanan diastolik yaitu tekanan saat otot jantung relaksasi dan menerima darah yang kembali dari seluruh tubuh dan nilai normalnya adalah 80 mmhg (Anri \& Khoiroh, 2017).

Menurut American Heart Association atau AHA, Hipertensi merupakan Silent Killer, dengan gejala yang dapat bervariasi pada masing masing individu dan hampir sama dengan gejala penyakit lainnya. Hipertensi merupakan faktor resiko untuk berbagai penyakit kardiovasculer dan stroke. Menurut AHA, hipertensi adalah penyakit yang terjadi karena adanya peningkatan tekanan darah sistolik $>140 \mathrm{mmhg}$ atau tekanan darah diastolik > 90 mmhg (Wahyudi, dkk, 2018).

Pada 2025 mendatang diperkirakan sekitar 29\% atau sebanyak 1,13 miliar warga dunia akan terkena hipertensi dan $2 / 3$ diantaranya berada di negara berkembang artinya 1 dari 3 orang didunia akan menderita hipertensi dan hanya 36,8\% diantaranya yang minum obat. Negara berkembang memiliki penderita hipertensi sebesar $40 \%$ sedangkan negara maju hanya 35\%, kawasan Afrika memegang posisi puncak yaitu sebesar 40\%, kawasan Amerika sebesar $35 \%$ dan Asia Tenggara 36\%. Kawasan Asia penyakit ini telah membunuh 1,5 juta orang setiap tahunnya. Sedangkan di Indonesia cukup tinggi, yakni mencapai 32\% dari total jumlah penduduk (Rakhmah, 2017).

Menurut data Sample Registration System (SRS), hipertensi di Indonesia pada tahun 2014, dengan komplikasi (5,3\%), merupakan penyebab kematian nomor 5 pada semua usia. Berdasarkan laporan Riskesdes 2013 prevalensi hipertensi berdasarkan hasil pengukuran pada penduduk usia 15-24 tahun (8,7\%), usia 25-34 tahun (14,7\%), usia 3544 tahun $(24,8 \%)$, usia 45-54 tahun $(35,6 \%)$, usia 55-64 tahun (45,9\%), usia 65-74 tahun $(57,6 \%)$, usia 75 tahun keatas $(63 \%, 8)$. Sedangkan Riskesdes 2018 berdasarkan hasil pengukuran pada penduduk usia 18-24 tahun (13.2\%), usia 25-34 tahun (20,1\%), usia 3544 tahun $(31,6 \%)$, usia 45-54 tahun $(45,3 \%)$, usia 55-64 tahun $(55,2 \%)$, usia 65-74 tahun 
$(63,2 \%)$, usia 75 tahun keatas $(69,5 \%)$. Secara fisiologis semakin tinggi usia seseorang maka semakin beresiko untuk mengidap hipertensi (Santoso, dkk).

Hipertensi pada lanjut usia sebagian besar merupakan Hipertensi Sistolik Terisolasi (HST). Prevalensi HST berturut-turut 7\% (usia 60-69), 11\% (usia 70-79), 18\% (usia 80-89), dan diatas 90 tahun. HST lebih sering ditemukan pada perempuan dari pada laki-laki. Pada penelitian di Rotterdam ditemukan dari 7.983 penduduk berusia diatas 55 tahun, prevalensi hipertensi $(160 / 95 \mathrm{mmHg})$ meningkat sesuai dengan umur, dimana perempuan (39\%) lebih tinggi dibandingkan laki-laki (31\%). Pada penelitian yang dilakukan di Taiwan menunjukkan hasil bahwa prevalensi hipertensi sebesar 60,4\% (lakilaki $59,1 \%$ dan perempuan $61,9 \%$ ), yang sebelumnya telah terdiagnosis hipertensi adalah $31,1 \%$ (laki-laki $29,4 \%$ dan perempuan $33,1 \%$ ), hipertensi yang baru terdiagnosis adalah $29,3 \%$ (laki-laki $29,7 \%$ dan perempuan $28,8 \%$ ), dimana ditemukan adanya riwayat keluarga dengan hipertensi dan tingginya indeks massa tubuh merupakan faktor risiko hipertensi (Kuswardhani, 2006).

Dari kedua laporan Riskesdes 2013 dan 2018 menunjukkan bahwa usia lanjut (55 keatas) prevalensinya semakin meningkat. Menurut Riskesdas Sumatera Utara 2018 data penderita hypertensi pada usia 55-64 sebanyak 13.02\%, usia 65-74 tahun sebanyak $18,07 \%$ dan usia 75 tahun keatas sebanyak 16,21\%. Lebih lanjut, pada Kabupaten Toba menurut data dari Badan Pusat Statistik Kabupaten Toba yang bersumber dari Dinas Kesehatan Kabupaten Toba 2020 hipertensi merupakan peringkat ketiga dari 10 penyakit terbesar dibawah Infeksi saluran penyakit atas dan Dispepsia. Jumlah penderita sebanyak 7032 dari jumlah penduduk 206.199 jiwa. Sedangkan pada UPT Puskesmas Sigumpar tempat dimana peneliti melakukan penelitian, jumlah penderita hipertensi pada lansia yang ditemukan pada pemeriksaan dokter di puskesmas dan pada pelaksanaan posyandu lansia sebanyak 50 orang dari jumlah lansia dikecamatan Sigumpar sebanyak 1.112 orang.

Mengacu pada latar belakang tersebut di atas maka perlu dilakukan penelitian tentang Faktor yang mempengaruhi Kejadian Hipertensi Pada Lanjut Usia (Lansia) di Wilayah Kerja UPT Puskesmas Sigumpar Tahun 2021.

\section{Metode Penelitian}

Desain penelitian yang digunakan dalam penelitian ini adalah survei analitik deskriptif dengan rancangan cross sectional yaitu suatu penelitian untuk mempelajari dinamika korelasi (hubungan) dan keterpengaruhan antara variabel independen terhadap variabel dependen pada saat yang bersamaan $(\mathrm{Hr}, 2018)$

Populasi dalam penelitian ini adalah seluruh lanjut usia ( $\geq 60$ tahun) penderita hipertensi di Wilayah kerja UPT Puskesmas Sigumpar sebanyak 102 orang, sampel yaitu 102 orang.

\section{Hasil dan Pembahasan}

\section{Karakteristik Responden}


Karakteristik responden yang diambil dalam penelitian ini mencakup umur, jenis kelamin, suku, pendidikan dan pekerjaan. Variabel independen mencakup obesitas, jumlah kalori, jenis makanan dan jadwal makan. Analisis univariat dilakukan untuk melihat distribusi frekuensi karakteristik responden dan distribusi frekuensi variabel independen (obesitas, riwayat keluarga, merokok, aktifitas fisik, pola makan dan etnis) serta variabel dependen (kejadian hipertensi).

Tabel 4.5. Karakteristik Responden Berdasarkan Umur di UPT Puskesmas Sigumpar Tahun 2021

\begin{tabular}{ccccc}
\hline No. & & Umur & $\mathrm{f}$ & Persentase \\
\hline 1 & $60-69$ tahun & 73 & 71.6 \\
2 & $70-79$ tahun & 23 & 22.5 \\
3 & $>80$ tahun & 6 & 5.9 \\
\hline & & Total & 102 & 100.0 \\
\hline
\end{tabular}

Berdasarkan tabel 4.5. diatas dapat dilihat bahwa mayoritas responden berumur 60-69 tahun yaitu sebanyak 73 responden $(71.6 \%)$ dan minoritas berumur $>80$ tahun yaitu sebanyak 6 responden (5.9\%).

Tabel 4.6. Karakteristik Responden Berdasarkan Jenis Kelamin di UPT Puskesmas Sigumpar Tahun 2021

\begin{tabular}{cllcc}
\hline No. & & Jenis Kelamin & $\mathrm{f}$ & Persentase \\
\hline 1 & Laki-laki & & 41 & 40.2 \\
2 & Perempuan & & 61 & 59.8 \\
\hline & & Total & 102 & 100.0 \\
\hline
\end{tabular}

Berdasarkan tabel diatas dapat dilihat bahwa mayoritas responden perempuan yaitu sebanyak 61 responden $(59.8 \%)$ dan minoritas Laki-laki yaitu sebanyak 41 responden $(40.2 \%)$.

Tabel 4.7. Karakteristik Responden Berdasarkan Pendidikan di UPT Puskesmas Sigumpar Tahun 2021

\begin{tabular}{clcc}
\hline No. & Pendidikan & f & Persentase \\
\hline 1 & SD/SMP & 20 & 19.6 \\
2 & SMA/SMK & 72 & 70.6 \\
3 & Perguruan Tinggi & 10 & 9.8 \\
\hline \multicolumn{2}{r}{ Total } & $\mathbf{1 0 2}$ & $\mathbf{1 0 0 . 0}$ \\
\hline
\end{tabular}

Berdasarkan tabel diatas dapat dilihat bahwa mayoritas responden memiliki pendidikan SMA/SMK yaitu sebanyak 72 responden $(70.6 \%)$ dan minoritas pendidikan SD/SMP yaitu sebanyak 20 responden (19.6\%).

Tabel 4.8. Karakteristik Responden Berdasarkan Pekerjaan di UPT Puskesmas Sigumpar Tahun 2021

\begin{tabular}{ccccc}
\hline No. & Pekerjaan & f & Persentase \\
\hline 1 & Ada & 76 & 74.5 \\
2 & Tidak Ada & 26 & 25.5 \\
\hline & & Total & $\mathbf{1 0 2}$ & $\mathbf{1 0 0 . 0}$ \\
\hline
\end{tabular}

Berdasarkan tabel diatas dapat dilihat bahwa mayoritas responden memiliki pekerjaan yaitu sebanyak 76 responden $(74.5 \%)$ dan minoritas tidak memiliki pekerjaan yaitu sebanyak 26 responden $(25.5 \%)$. 


\section{Analisis Univariat}

Analisis yang dilakukan menganalisis tiap variabel dari hasil penelitian. Tujuan dari analisis ini adalah untuk menjelaskan/mendeskripsikan karakteristik masing-masing variabel yang diteliti.

Tabel 4.9. Distribusi Frekuensi Responden Berdasarkan Riwayat Keluarga di UPT Puskesmas Sigumpar Tahun 2021

\begin{tabular}{cccc}
\hline No. & Riwayat Keluarga & $\mathrm{f}$ & Persentase \\
\hline 1 & Ada & 41 & 40.2 \\
2 & Tidak Ada & 61 & 59.8 \\
\hline & Total & 102 & 100.0 \\
\hline
\end{tabular}

Berdasarkan tabel diatas dapat dilihat bahwa mayoritas responden tidak ada riwayat keluarga hipertensi yaitu sebanyak 41 responden $(40.2 \%)$ dan minoritas ada riwayat keluarga hipertensi yaitu sebanyak 61 responden $(59.8 \%)$.

Tabel 4.10. Distribusi Frekuensi Responden Berdasarkan Merokok di

UPT Puskesmas Sigumpar Tahun 2021

\begin{tabular}{cccc}
\hline No. & Merokok & $\mathrm{f}$ & Persentase \\
\hline 1 & Merokok & 43 & 42.2 \\
2 & Tidak Merokok & 59 & 57.8 \\
\hline & Total & 102 & 100.0 \\
\hline
\end{tabular}

Berdasarkan tabel diatas dapat dilihat bahwa mayoritas responden tidak merokok yaitu sebanyak 55 responden $(53.9 \%)$ dan minoritas merokok yaitu sebanyak 47 responden $(46.1 \%)$.

Tabel 4.11. Distribusi Frekuensi Responden Berdasarkan Obesitas di UPT

Puskesmas

\begin{tabular}{|c|c|c|c|}
\hline \multicolumn{4}{|c|}{ Sigumpar Tahun 2021} \\
\hline No. & Obesitas & $\mathrm{f}$ & Persentase \\
\hline 1 & Obesitas & 55 & 53.9 \\
\hline 2 & Tidak Obesitas & 47 & 46.1 \\
\hline & Total & 102 & 100.0 \\
\hline
\end{tabular}

Berdasarkan tabel diatas dapat dilihat bahwa mayoritas responden tidak obesitas yaitu sebanyak 47 responden $(46.1 \%)$ dan minoritas obesitas yaitu sebanyak 55 responden $(53.9 \%)$.

Tabel 4.12. Distribusi Frekuensi Responden Berdasarkan Pola Makan di

UPT Puskesmas Sigumpar Tahun 2021

\begin{tabular}{clcc}
\hline No. & Pola Makan & f & Persentase \\
\hline 1 & Tidak Seimbang & 50 & 49.0 \\
2 & Seimbang & 52 & 51.0 \\
\hline \multicolumn{2}{c}{ Total } & 102 & 100.0 \\
\hline
\end{tabular}

Berdasarkan tabel diatas dapat dilihat bahwa mayoritas responden memiliki pola makan seimbang yaitu sebanyak 52 responden (51.0\%) dan minoritas memiliki pola makan tidak seimbang yaitu sebanyak 50 responden (49.0\%).

Tabel 4.13. Distribusi Frekuensi Responden Berdasarkan Aktifitas Fisik di

UPT Puskesmas Sigumpar Tahun 2021

\begin{tabular}{llll}
\hline No. & Aktifitas Fisik & f & Persentase \\
\hline
\end{tabular}




\begin{tabular}{lccc}
\hline 1 & Berat & 44 & 43.1 \\
2 & Ringan & 58 & 56.9 \\
\hline & Total & 102 & 100.0 \\
\hline
\end{tabular}

Berdasarkan tabel diatas dapat dilihat bahwa mayoritas responden memiliki aktifitas ringan yaitu sebanyak 58 responden (56.9\%) dan minoritas memiliki aktifitas berat yaitu sebanyak 44 responden $(43.1 \%)$.

Tabel 4.14. Distribusi Frekuensi Responden Berdasarkan Etnis di UPT

Puskesmas Sigumpar Tahun 2021

\begin{tabular}{clccc}
\hline No. & Etnis & $\mathrm{f}$ & Persentase \\
\hline 1 & Jawa & & 22 & 21.6 \\
2 & Batak & 68 & 66.7 \\
3 & Padang & 12 & 11.8 \\
\hline & & Total & 102 & 100.0 \\
\hline
\end{tabular}

Berdasarkan tabel diatas dapat dilihat bahwa mayoritas responden suku batak yaitu sebanyak 68 responden $(66.7 \%)$ dan minoritas suku padang yaitu sebanyak 12 responden $(11.8 \%)$.

Tabel 4.15. Distribusi Frekuensi Responden Berdasarkan Kejadian Hipertensi di UPT Puskesmas Sigumpar Tahun 2021

\begin{tabular}{cccc}
\hline No. & Kejadian Hipertensi & $\mathrm{f}$ & Persentase \\
\hline 1 & Ya & 55 & 53.9 \\
2 & Tidak & 47 & 46.1 \\
\hline & Total & 102 & 100.0 \\
\hline
\end{tabular}

Berdasarkan tabel diatas dapat dilihat bahwa mayoritas responden tidak mengalami kejadian hipertensi yaitu sebanyak 47 responden $(46.1 \%)$ dan minoritas mengalami kejadian hipertensi yaitu sebanyak 55 responden (53.9\%).

\section{Analisis Bivariat}

\section{Tabulasi dan Hasil Uji Statistik}

Analisis Bivariat dilakukan untuk mengetahui hubungan variabel independen dan variabel dependen melalui Crosstabs atau tabulasi silang. Uji statistik yang dilakukan pada analisis Bivariat ini adalah menggunakan uji Chi-Square dengan derajat kepercayaan $95 \%(\alpha=0,05)$. Dikatakan ada hubungan secara statistik jika diperoleh nilai $p<0,05$.

Tabel 4.16. Hubungan Riwayat Keluarga Dengan Kejadian Hipertensi di UPT Puskesmas Sigumpar Tahun 2021

\begin{tabular}{|c|c|c|c|c|c|c|c|}
\hline \multirow{3}{*}{ Riwayat Keluarga } & \multicolumn{4}{|c|}{ Kejadian Hipertensi } & \multirow{2}{*}{\multicolumn{2}{|c|}{ Jumlah }} & \multirow{3}{*}{$p$ (value) } \\
\hline & \multicolumn{2}{|r|}{$\mathrm{Ya}$} & \multicolumn{2}{|c|}{ Tidak } & & & \\
\hline & $\mathrm{f}$ & $\%$ & $\mathrm{f}$ & $\%$ & $\mathrm{f}$ & $\%$ & \\
\hline Ada & 38 & 92.7 & 3 & 7.3 & 41 & 100 & \\
\hline Tidak Ada & 9 & 14.8 & 52 & 85.2 & 61 & 100 & 0,000 \\
\hline Total & 47 & & 55 & & 102 & & \\
\hline
\end{tabular}


Berdasarkan tabel diatas dapat dilihat bahwa dari 41 responden yang memiliki riwayat keluarga hipertensi terdapat 38 responden $(92.7 \%)$ mengalami kejadian hipertensi dan 3 responden (7.3\%) tidak mengalami kejadian hipertensi. Dari 61 responden yang tidak memiliki riwayat keluarga hipertensi terdapat 9 responden (14.8\%) mengalami kejadian hipertensi dan 52 responden (85.2\%) tidak mengalami kejadian hipertensi.

Berdasarkan analisis statistik Chi Square Test didapat nilai $p$-value $0.000<0.05$ sehingga dapat disimpulkan bahwa terdapat hubungan riwayat keluarga hipertensi terhadap kejadian hipertensi pada lansia di UPT Puskesmas Sigumpar.

Tabel 4.17. Hubungan Merokok Dengan Kejadian Hipertensi di UPT

Puskesmas Sigumpar Tahun 2021

\begin{tabular}{|c|c|c|c|c|c|c|c|}
\hline \multirow{3}{*}{ Merokok } & \multicolumn{4}{|c|}{ Kejadian Hipertensi } & \multirow{2}{*}{\multicolumn{2}{|c|}{ Jumlah }} & \multirow{3}{*}{$p$ (value) } \\
\hline & \multicolumn{2}{|r|}{$\mathrm{Ya}$} & \multicolumn{2}{|c|}{ Tidak } & & & \\
\hline & $\mathrm{f}$ & $\%$ & $\mathrm{f}$ & $\%$ & $\mathrm{f}$ & $\%$ & \\
\hline Merokok & 41 & 95.3 & 2 & 4.7 & 43 & 100 & \\
\hline Tidak merokok & 6 & 10.2 & 53 & 89.8 & 59 & 100 & 0,000 \\
\hline Total & 47 & & 55 & & 102 & & \\
\hline
\end{tabular}

Berdasarkan tabel diatas dapat dilihat bahwa dari 43 responden yang merokok terdapat 41 responden (95.3\%) mengalami kejadian hipertensi dan 2 responden (4.7\%) tidak mengalami kejadian hipertensi. Dari 59 responden yang tidak merokok terdapat 6 responden (10.2\%) mengalami kejadian hipertensi dan 53 responden (89.8\%) tidak mengalami kejadian hipertensi.

Berdasarkan analisis statistik Chi Square Test didapat nilai p-value $0.000<0.05$ sehingga dapat disimpulkan bahwa terdapat hubungan merokok terhadap kejadian hipertensi pada lansia di UPT Puskesmas Sigumpar.

Tabel 4.18. Hubungan Obesitas Dengan Kejadian Hipertensi di UPT Puskesmas Sigumpar Tahun 2021

\begin{tabular}{|c|c|c|c|c|c|c|c|}
\hline \multirow{3}{*}{ Obesitas } & \multicolumn{4}{|c|}{ Kejadian Hipertensi } & \multirow{2}{*}{\multicolumn{2}{|c|}{ Jumlah }} & \multirow{3}{*}{$p$ (value) } \\
\hline & \multicolumn{2}{|c|}{ Ya } & \multicolumn{2}{|c|}{ Tidak } & & & \\
\hline & $\mathbf{f}$ & $\%$ & $\mathbf{f}$ & $\%$ & f & $\%$ & \\
\hline Obesitas & 33 & 70.2 & 14 & 29.8 & 47 & 100 & \\
\hline Tidak Obesitas & 14 & 25.5 & 41 & 74.5 & 55 & 100 & 0,000 \\
\hline Total & 47 & & 55 & & 102 & & \\
\hline
\end{tabular}

Berdasarkan tabel diatas dapat dilihat bahwa dari 47 responden yang mengalami obesitas terdapat 33 responden $(70.2 \%)$ mengalami kejadian hipertensi dan 14 responden (29.8\%) tidak mengalami kejadian hipertensi. Dari 55 responden yang tidak mengalami obesitas terdapat 14 responden $(25.5 \%)$ mengalami kejadian hipertensi dan 41 responden (74.5\%) tidak mengalami kejadian hipertensi.

Berdasarkan analisis statistik Chi-Square didapat nilai $p$-value $0.000<0.05$ sehingga dapat disimpulkan bahwa terdapat hubungan obesitas terhadap kejadian hipertensi pada lansia di UPT Puskesmas Sigumpar.

Tabel 4.19. Hubungan Pola Makan Dengan Kejadian Hipertensi di UPT

Puskesmas Sigumpar Tahun 2021 


\begin{tabular}{|c|c|c|c|c|c|c|c|}
\hline \multirow{3}{*}{ Pola Makan } & \multicolumn{4}{|c|}{ Kejadian Hipertensi } & \multirow{2}{*}{\multicolumn{2}{|c|}{ Jumlah }} & \multirow{3}{*}{$p$ (value) } \\
\hline & \multicolumn{2}{|c|}{$\mathrm{Ya}$} & \multicolumn{2}{|c|}{ Tidak } & & & \\
\hline & $\mathrm{f}$ & $\%$ & $\mathrm{f}$ & $\%$ & $\mathrm{f}$ & $\%$ & \\
\hline Tidak Seimbang & 44 & 80.0 & 6 & 12.0 & 50 & 100 & \multirow{3}{*}{0,000} \\
\hline Seimbang & 3 & 5.8 & 49 & 94.2 & 52 & 100 & \\
\hline Total & 47 & & 55 & & 102 & & \\
\hline
\end{tabular}

Berdasarkan tabel diatas dapat dilihat bahwa dari 50 responden yang memiliki pola makan tidak seimbang terdapat 44 responden $(88.0 \%)$ mengalami kejadian hipertensi dan 6 responden (12.0\%) tidak mengalami kejadian hipertensi. Dari 52 responden yang memiliki pola makan tidak seimbang terdapat 3 responden (5.8\%) mengalami kejadian hipertensi dan 49 responden (94.2\%) tidak mengalami kejadian hipertensi.

Berdasarkan analisis statistik Chi Square Test didapat nilai $p$-value $0.000<0.05$ sehingga dapat disimpulkan bahwa terdapat hubungan pola makan terhadap kejadian hipertensi pada lansia di UPT Puskesmas Sigumpar.

Tabel 4.20. Hubungan Aktifitas Fisik Dengan Kejadian Hipertensi di UPT Puskesmas Sigumpar Tahun 2021

\begin{tabular}{|c|c|c|c|c|c|c|c|}
\hline \multirow{3}{*}{ Aktifitas Fisik } & \multicolumn{4}{|c|}{ Kejadian Hipertensi } & \multirow{2}{*}{\multicolumn{2}{|c|}{ Jumlah }} & \multirow{3}{*}{$p$ (value) } \\
\hline & \multicolumn{2}{|c|}{ Ya } & \multicolumn{2}{|c|}{ Tidak } & & & \\
\hline & $\mathbf{f}$ & $\%$ & f & $\%$ & $\mathbf{f}$ & $\%$ & \\
\hline Berat & 43 & 97.7 & 1 & 2.3 & 40 & 100 & \multirow{3}{*}{0,000} \\
\hline Ringan & 4 & 6.9 & 54 & 93.1 & 58 & 100 & \\
\hline Total & 47 & & 55 & & 102 & & \\
\hline
\end{tabular}

Berdasarkan tabel diatas dapat dilihat bahwa dari 44 responden yang memiliki aktifitas fisik berat terdapat 43 responden (97.7\%) mengalami kejadian hipertensi dan 1 responden $(2.3 \%)$ tidak mengalami kejadian hipertensi. Dari 58 responden yang memiliki aktifitas fisik ringan terdapat 4 responden (6.9\%) mengalami kejadian hipertensi dan 54 responden $(93.1 \%)$ tidak mengalami kejadian hipertensi.

Berdasarkan analisis statistik Chi Square Test didapat nilai $p$-value $0.000<0.05$ sehingga dapat disimpulkan bahwa terdapat hubungan aktifitas fisik terhadap kejadian hipertensi pada lansia di UPT Puskesmas Sigumpar.

Tabel 4.21. Hubungan Etnis Dengan Kejadian Hipertensi di UPT

Puskesmas Sigumpar Tahun 2021

\begin{tabular}{|c|c|c|c|c|c|c|c|}
\hline \multirow{3}{*}{ Etnis } & \multicolumn{4}{|c|}{ Kejadian Hipertensi } & \multirow{2}{*}{\multicolumn{2}{|c|}{ Jumlah }} & \multirow{3}{*}{$p$ (value) } \\
\hline & \multicolumn{2}{|c|}{ Ya } & \multicolumn{2}{|c|}{ Tidak } & & & \\
\hline & $\mathbf{f}$ & $\%$ & f & $\%$ & $f$ & $\%$ & \\
\hline Jawa & 18 & 81.8 & 4 & 18.2 & 22 & 100 & \multirow{4}{*}{0,000} \\
\hline Batak & 23 & 33.8 & 45 & 66.2 & 68 & 100 & \\
\hline Padang & 6 & 50.0 & 6 & 50.0 & 12 & & \\
\hline Total & 47 & & 55 & & 102 & & \\
\hline
\end{tabular}

Berdasarkan tabel diatas dapat dilihat bahwa dari 22 responden yang bersuku Jawa terdapat 18 responden $(81.8 \%)$ mengalami kejadian hipertensi dan 4 responden (18.2\%) tidak mengalami kejadian hipertensi. Dari 68 responden yang bersuku Batak 
terdaApat 23 responden (33.8\%) mengalami kejadian hipertensi dan 45 responden (66.2\%) tidak mengalami kejadian hipertensi. Dari 12 responden yang bersuku Batak terdapat 6 responden $(50.0 \%)$ mengalami kejadian hipertensi dan 6 responden $(50.0 \%)$ tidak mengalami kejadian hipertensi.

Berdasarkan analisis statistik Chi-Square Test didapat nilai $p$-value $0.000<0.05$ sehingga dapat disimpulkan bahwa terdapat hubungan suku terhadap kejadian hipertensi pada lansia di UPT Puskesmas Sigumpar.

\section{Analisis Multivariat}

Tabel 4.22. Tabel Variabel yang memenuhi syarat Uji Multivariat

\begin{tabular}{|c|c|c|}
\hline Variabel & P-value & Keterangan \\
\hline Riwayat Keluarga & 0.001 & Memenuhi syarat \\
\hline Merokok & 0.001 & Memenuhi syarat \\
\hline Obesitas & 0.001 & Memenuhi syarat \\
\hline Pola Makan & 0.001 & Memenuhi syarat \\
\hline Aktifitas Fisik & 0.001 & Memenuhi syarat \\
\hline Etnis & 0.001 & Memenuhi syarat \\
\hline
\end{tabular}

Analisis ini untuk melihat pengaruh (hubungan) antara variabel independen yaitu Riwayat keluarga, merokok, obesitas, pola makan, aktivitas fisik dan etnis terhadap variabel dependen yaitu kejadian hipertensi dengan jenis analisa regresi logistik sehingga didapat variabel independen yang paling dominan mempengaruhi variabel dependen.

\section{Pengaruh Karakteristik Responden Dengan Kejadian Hipertensi di UPT Puskesmas Sigumpar Tahun 2021.}

Pusat Kesehatan Masyarakat (Puskesmas) adalah unit pelaksana teknis dinas kabupaten/kota yang bertanggungjawab menyelenggarakan pembangunan kesehatan di suatau wilayah kerja. Jadi dengan adanya puskesmas di setiap kecamatan atau tingkat lebih rendah lainnya diharapkan seluruh warga mendapat akses pelayanan kesehatan yang merata. Puskesmas ini adalah unit pelaksana fungsional yang berfungsi sebagai pusat pembangunan kesehatan, pusat pembinaan peran serta masyarakat dalam bidang kesehatan serta pusat pelayanan kesehatan tingkat pertama yang menyelenggarakan kegiatannya secara menyeluruh, terpadu yang berkesinambungan pada suatu masyarakat yang bertempat tinggal dalarn suatu wilayah tertentu.

Hipertensi atau tekanan darah tinggi adalah suatu peningkatan abnormal tekanan darah dalam pembuluh darah arteri secara terus menurus lebih dari suatu periode. Hal ini terjadi bila arteriola-arteriola kontriksi. Kontriksi arteriola membuat darah sulit mengalir dan meningkatkan tekanan melawan dinding arteri. Hipertensi menambah beban kerja jantung, dan arteri yang bila berlanjut dapat menimbulkan kerusakan jantung dan pembuluh darah. Hipertensi adalah tekanan darah ditandai dengan tekanan darah >140/90 $\mathrm{mmHg}$.

Hipertensi merupakan penyakit yang dapat dicegah dengan mengendalikan faktor risiko yang sebagian besar merupakan faktor perilaku dan kebiasaan hidup. Apabila seseorang menerapkan gaya hidup sehat, maka kemungkinan besar akan terhindar dari hipertensi. Penyakit ini berjalan terus seumur hidup dan sering tanpa adanya keluhan 
yang selama belum terjadi komplikasi pada organ tubuh. Terdapat beberapa faktor risiko yang menyebabkan terjadinya hipertensi, antara lain faktor genetik/riwayat keluarga, umur, jenis kelamin, etnis, stress, pola makan, obesitas, asupan garam, penggunaan obat hormonal, dan kebiasaan merokok.

Penelitian Oleh Azhar (2020) Dengan Judul Penelitian Karakteristik Pasien Hipertensi Di Puskesmas Gamping I Sleman Yogyakarta.

Menurut temuan peneliti karakteristik responden baik dari dari segi umur, jenis kelamin, pendidikan, pendikan dan pekerjaan sangat berperan dalam kejadian hipertensi di UPT Puskesmas Sigumpar Tahun 2021.Hipertensi dipengaruhi oleh faktor risiko yang dapat dikontrol dan tidak dapat dikontrol. Faktor yang tidak dapat dikontrol meliputi umur, jenis kelamin, suku, stres, dan faktor genetik sedangkan faktor yang dapat dikontrol antara lain konsumsi garam, kebiasaan olahraga, kebiasaan merokok dan obesitas. Kemunduran fungsi organ tubuh khususnya pada lansia menyebabkan kelompok ini rawan terhadap serangan berbagai penyakit kronis, penyakit yang sering dijumpai pada lansia adalah hipertensi.

\section{Pengaruh Riwayat Keluarga Dengan Kejadian Hipertensi di UPT Puskesmas Sigumpar Tahun 2021.}

Riwayat keluarga yaitu riwayat keturunan yang dimiliki dan berhubungan dengan hipertensi yaitu ibu, bapak dan tidak langsung yaitu kakek kandung dan nenek kandung. Seseorang cenderung menderita tekanan darah tinggi bila kedua orang tuanya juga menderita tekanan darah tinggi. Menurut WHO, riwayat keluarga yang menunjukkan adanya tekanan darah yang meninggi merupakan faktor risiko paling kuat bagi seseorang untuk mengidap hipertensi di masa datang. Hal ini menunjukkan bahwa gen yang diturunkan, dan bukan hanya faktor lingkungan (seperti makanan atau status sosial), berperan besar dalam menentukan tekanan darah.

Berdasarkan analisis statistik Chi Square Test didapat nilai p-value $0.000<0.05$ sehingga dapat disimpulkan bahwa terdapat hubungan riwayat keluarga hipertensi terhadap kejadian hipertensi pada lansia di UPT Puskesmas Sigumpar.

Penelitian ini sejalan dengan penelitian Zahwan (2019) dengan judul penelitian Hubungan Riwayat Keluarga Hipertensi Dan Kebiasaan Merokok Terhadap Kejadian Hipertensi Pada Remaja Di SMA Kota Palembang. Hasil penelitian menunjukkan analisis chi-square menunjukan adanya hubungan yang signifikan antara riwayat keluarga menderita hipertensi terhadap kejadian hipertensi Kesimpulan: Terdapat hubungan yang bermakna antara riwayat keluarga menderita hipertensi terhadap kejadian hipertensi pada remaja dan tidak terdapat hubungan yang bermakna antara kebiasaan merokok terhadap kejadian hipertensi pada remaja di SMA Kota Palernbang.

\section{Pengaruh Merokok Dengan Kejadian Hipertensi di UPT Puskesmas Sigumpar Tahun 2021.}

Merokok merupakan suatu kebiasaan yang merugikan kesehatan. Kebiasaan ini terkadang sulit dihentikan karena adanya efek ketergantungan yang ditimbulkan oleh 
nikotin. Selain itu, akibat yang ditimbulkan seperti penyakit akibat rokok, terjadi dalam jangka waktu yang cukup lama sehingga sering kali menyebabkan kegagalan dalam upaya mencegah untuk tidak merokok atau menghentikan kebiasaan merokok.

Berdasarkan analisis statistik Chi Square Test didapat nilai $p$-value $0.000<0.05$ sehingga dapat disimpulkan bahwa terdapat hubungan merokok terhadap kejadian hipertensi pada lansia di UPT Puskesmas Sigumpar.

Penelitian ini sejalan dengan penelitian Dessy Kristina Magai (2021) dengan judul penelitian Hubungan Perilaku

Penelitian lain yang juga bertolak belakang dengan Penelitian Ini Eric Untario (2018) Dengan Judul Penelitian Hubungan Merokok Terhadap Kejadian Hipertensi. Hasil: Pada penelitian ini responden yang berpartisipasi paling banyak ditemukan pada kelompok umur 41 - 50 tahun yaitu sebanyak 32 orang $(31,37 \%)$. Responden yang merokok sebanyak 34 orang $(33,3 \%)$ dengan tekanan darah normal sebanyak 39 orang $(38,2 \%)$ dan hipertensi 63 orang $(61,8 \%)$. Hasil penelitian didapatkan tidak ada hubungan antara kebiasaan merokok dengan kejadian hipertensi $(\mathrm{p}=0,387)$ yang dipengaruhi oleh jenis rokok $(\mathrm{p}=0,43)$ dan derajat merokok $(\mathrm{p}=0,761)$. Kesimpulan Tidak terdapat hubungan antara kebiasaan merokok dengan kejadian hipertensi.

Menurut temuan peneliti Nikotin yang ada di dalam rokok dapat mempengaruhi tekanan darah seseorang, dapat melalui pembentukan plak aterosklerosis, efek langsung nikotin terhadap pelepasan hormon epinefrin dan norepinefrin, maupun melalui efek CO yang dapat berikatan dengan sel darah merah. Di samping itu, nikotin akan meningkatkan tekanan darah dengan merangsang pelepasan sistem humoral kimia, yaitu norephinephrin melalui saraf 41 adrenergik dan meningkatkan katekolamin yang dikeluarkan oleh medula adrenal. Akibatnya, terjadi perubahan diameter pembuluh darah (penyempitan pembuluh darah), maka akan terjadi perubahan pada nilai osmotik dan tekanan hidrostatis di dalam vaskuler dan di ruang-ruang interstisial di luar pembuluh darah. Tekanan hidrostatis dalam vaskuler akan meningkat, sehingga tekanan darah juga akan meningkat.

Seseorang yang memiliki kebiasaan mengonsumsi rokok dan sering tekena asap yang dikeluarkan dari rokok sangat beresiko mengalami hipertensi. Asap rokok sangat mempengaruhi peningkatan tekanan darah hal ini dikarenakan didalam asap rokok mengandung kurang lebih 4000 bahan kimia, sekitar 200 jenis bahan kimia yang beracun, dan 43 jenis lainnya dapat mengakibatkan kanker bagi tubuh, rokok mengandung bahan kimia yang membahayakan tubuh, zat berbahaya tersebut salah satunya adalah nikotin. Seseorang yang bukan perokok tetapi menghirup asap rokok memiliki resiko dua kali lebih besar terkena hipertensi. Pasien yang berobat di UPT Puskesmas Sigumpar banyak yang mengalami hipertensi akibat kebiasan merokok.

\section{Pengaruh Obesitas Dengan Kejadian Hipertensi di UPT Puskesmas Sigumpar Tahun 2021.}

Obesitas (kegemukan) yaitu ketidakseimbangan antara jumlah makanan yang masuk dibandingkan dengan pengeluaran energy oleh tubuh atau suatu keadaan dari 
akumulasi lemak tubuh yang berlebihan di jaringan lemak suatu organ tertentu. Semakin besar massa tubuh seseorang maka akan semakin banyak darah yang dibutuhkan untuk menyuplai oksigen dari nutrisi ke otot dan jaringan lain. Obesitas bisa meningkatkan jumlah panjangnya pembuluh darah sehingga dapat meningkatkan resistensi darah yang seharusnya mampu menempuh jarak lebih jauh dan tekanan darah akan menjadi tinggi (Sani, 2015). Obesitas berhubungan erat dengan hipertensi, dengan peningkatan tekanan darah sistolik (SBP) $6,5 \mathrm{mmHg}$ untuk setiap kenaikan 10 persen berat badan.

Diketahui bahwa penduduk wilayah UPT Puskesmas Sigumpar umumnya adalah suku batak toba $( \pm 75 \%)$, suku jawa $( \pm 10 \%)$ dan suku padang $( \pm 5 \%)$. Kebiasaan makan wajib makan pokok 3 kali sehari, nasi, lauk dan sayur selalu tersedia, namun terkadang hanya mengkonsumsi nasi dan lauk saja, ada juga nasi dan sayur saja, mie instan dan nasi, mengkonsumsi makanan dan minuman yang manis, seperti setiap pagi, sore, dan malam hari selalu mengkonsumsi makanan seperti mie gomak goreng/kuah, mie harsot dan mengkonsumsi minuman manis seperti teh dan kopi, belum lagi apabila berkunjung ke rumah tetangga pasti akan dijamu dengan minuman seperti teh, sirup dan kopi. Makanan cemilan atau snack seperti kolak pisang, bubur, getuk, klepon (buah malaka) dan lain sebagainya.

Penelitian ini sejalan dengan penelitian Ulfa intan tiara (2020) dengan judul penelitian Hubungan Obesitas Dengan Kejadian Hipertensi. Hasil penelitian penyakit hipertensi bagi beberapa orang tidak memiliki keluhan apapun namun jika penyakit hipertensi tidak terkontrol dengan baik maka dapat timbul beberapa komplikasi yang spesifik pada organ seperti otak, mata, ginjal, jantung, pembuluh darah, atau organ-organ vital lainnya. Ada beberapa faktor risiko untuk terjadinya penyakit hipertensi yaitu genetik, usia, jenis kelamin dan gaya pola hidup tidak sehat. Gaya pola hidup yang tidak sehat salah satunya adalah bisa terjadinya berat badan berlebih atau obesitas. Dengan adanya penyakit obesitas pada seseorang diduga memiliki hubungan yang bermakna dengan kejadian hipertensi.

Penelitian lain yang juga sejalan Dengan Penelitian ini oleh Safitri (2020) Dengan Judul Penelitian Hubungan Obesitas Dengan Kejadian Hipertensi Pada Masyarakat Di Desa Air Tiris Wilayah Kerja Uptd Puskesmas Kampar. Hasil penelitian di dapatkan bahwa ada hubungan yang signifikan antara obesitas dengan kejadian hipertensi pada masyarakat di Desa Air Tiris Wilayah Kerja UPTD Puskesmas Kampar Tahun 2019 dengan nilai p-value $=0.004<0.05$. Berdasarkan hasil penelitian ini disarankan kepada responden agar dapat mengontrol tekanan darah dengan memperbaiki gaya hidup yang kurang baik seperti pola makan yang tidak sehat dan kurang olahraga.

\section{Pengaruh Pola makan Dengan Kejadian Hipertensi di UPT Puskesmas Sigumpar Tahun 2021.}

Pola makan adalah Pola makan merupakan waktu makan secara seimbang baik karbohidrat, lemak dan serat. Kebiasaan konsumsi makanan merupakan rutinitas seseorang dalam mengonsumsi makanan sehari-hari yang telah menjadi kebiasaan makan. Kebiasaan konsumsi makanan diartikan sebagai perilaku dalam mengonsumsi makan pada individu yang dilakukan berulang-ulang untuk memenuhi kebutuhannya sehingga membentuk karakteristik pada setiap orang. Kebiasaan konsumsi makanan dinilai berdasarkan asupan makanan, jenis makanan dan frekuensi makan. Kebiasaan konsumsi makanan pada penelitian ini dilihat dari kebiasaan konsumsi asupan zat gizi lemak dan 
natrium.

Berdasarkan analisis statistik Chi Square Test didapat nilai $p$-value $0.000<0.05$ sehingga dapat disimpulkan bahwa terdapat hubungan pola makan terhadap kejadian hipertensi pada lansia di UPT Puskesmas Sigumpar. Penelitian ini sejalan dengan penelitian Siti Nur hasanah (2020) dengan judul peneltian Hubungan pola makan dengan kejadian hipertensi lansia di puskesmas Menur Surabaya.

Penelitian Lain Yang Juga Sejalan Dengan Penelitian Ini Oleh Hamzah B, Dengan Judul Penelitian Analisis Hubungan Pola Makan Dengan Kejadian Hipertensi Pada Lansia. asil penelitian menunjukkan terdapat $61,3 \%$ responden yang menderita hipertensi, 67,7\% responden yang memiliki pola makan kurang baik dan 32,3\% yang memiliki pola makan yang baik. Hasil uji statistik diperoleh ada hubungan pola makan dengan kejadian hipertensi $(\mathrm{p}=0,014<0,05)$. Maka dapat disimpulkan ada hubungan antara pola makan dengan kejadian hipertensi di wilayah kerja Puskesmas Molibagu Kabupaten Bolaang Mongondow Selatan. Saran kepada masyarakat khususnya pada lansia untuk selalu mengontrol tekanan darah dan menjaga pola makan yang sehat dengan menghindari makanan yang tinggi natrium dan berlemak.

Kebiasaan konsunmsi makanan ini merupakan bentuk dari gaya hidup yang tidak sehat. Gaya hidup yang tidak sehat ini dikarenakan ketidaktahuan para pasien di UPT Puskesmas Sigumpar, bahwa salah satu pemicu hipertensi adalah konsumsi asupan lemak yang berlebih. Ketidaktahuan ini dikarenakan pasien ada yang bekerja sebagai petani hampir tidak pernah mengikuti penyuluhan/kegiatan posbindu terkait PTM khususnya hiprtensi yang dilaksanakan oleh puskesmas. Alasan mereka hampir tidak pernah mengikuti kegiatan tersebut karena kegiatan tersebut berhalangan dengan kegiatan mereka yang bekerja di ladang dari pagi hingga sore hari.

\section{Pengaruh Aktivitas Fisik Dengan Kejadian Hipertensi di UPT Puskesmas Sigumpar Tahun 2021.}

Aktivitas fisik merupakan keselurahan kegiatan masyarakat meliputi kegiatan olahraga, pekerjaan sehari-hari yang mana diperoleh dengan menggunakan formulir PAL aktivitas fisik 1x24 jam.

Berdasarkan analisis statistik Chi Square Test didapat nilai $p$-value $0.000<0.05$ sehingga dapat disimpulkan bahwa terdapat hubungan aktifitas fisik terhadap kejadian hipertensi pada lansia di UPT Puskesmas Sigumpar.

Penelitian ini sejalan dengan penelitian Grisda ledia day (2020) dengan judul penelitian Hubungan Aktivitas Fisik Terhadap Kejadian Hipertensi Pada Wanita Pralansia Di Puskesmas Bakunase. Hasil penelitian diuji dengan uji spearman. Hasil tingkat aktivitas fisik terbanyak yang dilakukan wanita pralansia di Puskesmas Bakunase adalah jenis aktivitas fisik ringan dengan jumlah 39 orang (65\%). Mayoritas responden penelitian ini memiliki tekanan darah prahipertensi sebanyak 26 orang $(43,3 \%)$. Hasil analisis data menggunakan uji spearman menunjukkan ada hubungan signifikan antara aktivitas fisik terhadap kejadian hipertensi pada wanita pralansia di Puskesmas Bakunase Kupang $(\mathrm{p}=0,024)$, namun hasil penelitian ini memiliki kolerasi sangat lemah $(\mathrm{r}=-0,291)$ dengan sifat kolerasi negatif yaitu semakin rendah aktivitas fisik maka semakin tinggi 
tekanan darah. Kesimpulan dari penelitian ini ada hubungan signifikan antara aktivitas fisik terhadap kejadian hipertensi pada wanita pralansia di Puskesmas Bakunase Kupang.

Penelitian Lain Yang Sejalan Dengan Penelitian Muhamad Cristanto (2021) Dengan Judul Penelitian Hubungan Aktivitas Fisik Dengan Pencegahan Hipertensi Pada Usia Dewasa Muda. Berdasarkan hasil penelitian didapatkan hasil bahwa aktifitas fisik secara signifikan menurunkan tekanan darah sistolik dan diastolik dan dapat mencegah Hipertensi serta penyakit tidak menular lainnya. Lama aktifitas fisik yang dianjurkan untuk mencegah hipertensi adalah 150 menit, dengan frekuensi lima hari atau lebih dalam seminggu. Orang dewasa muda harus menyadari dan melakukan aktifitas fisik sesuai dengan rekomendasi, untuk mencegah Hipertensi. Saran bagi penyedia layanan kesehatan, harus memberikan pendidikan kesehatan secara rutin kepada penderita Hipertensi khususnya tentang aktifitas fisik.

Penyebab utama meningkatnya penyakit PTM terutama di Indonesia adalah gaya hidup yang modern yang minim aktivitas dan gerakan fisik atau sendentary. Aktivitas fisik adalah gerakan tubuh yang dihasilkan otot rangka yang memerlukan suatu pengeluaran energi, aktivitas fisik yang kurang merupakan faktor risiko independen untuk pennyakit kronis dan secara umum diperkirakan menyebabkan kematian secara global. Contoh dari aktivitas fisik yang dapat menjaga kestabilan tekanan darah misalnya turun bus lebih awal menuju tempat kerja yang kira-kira menghabiskan 20 menit berjalan kaki dan saat pulang berhenti dihalte yang menghabiskan kira-kira 10 menit berjalan kaki menuju rumah, atau membersihkan rumah selama 10 menit ditambah bersepeda 10 menit dan lain-lain.

Pentingnya berolahraga dan bergerak badan sejak kecil demi terbentuknya otototot jantung yang lebih tangguh. Jantung yang tangguh tetap kuat memompa darah kendati menghadapi rintangan pipa pembuluh darah yang sudahtidak utuh lagi. Jantung yang terlati sejakusia muda ototnya lebih tebal dan kuat dibanding yang tidak terlatih.

\section{Pengaruh Etnis Dengan Kejadian Hipertensi di UPT Puskesmas Sigumpar Tahun 2021.}

Etnis adalah merupakan suatu kesatuan sosial yang dapat dibedakan dari kesatuanyang lain berdasarkan akar dan identitas kebudayaan, terutama bahasa. Dengan kata lain etnis adalah kelompok manusia yang terikat oleh kesadaran dan identitas tadi sering kali dikuatkan oleh kesatuan bahasa.

Berdasarkan analisis statistik Chi-Square Test didapat nilai p-value $0.000<0.05$ sehingga dapat disimpulkan bahwa terdapat hubungan suku terhadap kejadian hipertensi pada lansia di UPT Puskesmas Sigumpar.

Penelitian ini sejalan dengan penelitian lailatul saidah (2019) dengan judul penelitian Analisis Faktor Yang Memengaruhi Kejadian Hipertensi Pada Suku Batak Di Wilayah Kerja Puskesmas Cikampak Kabupaten Labuhan Batu Selatan. erdasarkan hasil penelitian diketahui bahwa kejadian hipertensi berhubungan dengan umur $(\mathrm{p}=0,033)$, pola makanan $(\mathrm{p}=0,017)$, konsumsi kopi $(\mathrm{p}=0,000)$. Berdasarkan hasil penelitian, dapat disimpulkan bahwa faktor-faktor yang berhubungan dengan kejadian hipertensi 
berhubungan dengan umur, pola makanan, konsumsi kopi. Sehingga adapun saran dalam penelitian ini diharapkan agar penderita hipertensi mengurangi konsumsi yang berhubungan dengan kejadian hipertensi dan melakukan pemeriksaan rutin di Wilayah Kerja Puskesmas Cikampak Kabupaten Labuhan Selatan.

Penelitian ini bertolak belakang dengan penelitian lailatul saidah (2019) dengan judul penelitian Perbedaan Faktor Penderita Hipertensi pada Suku Jawa dan Suku Madura. Hasil analisis bivariat menggunakan uji Chi Square menunjukkan tidak adanya perbedaan kejadian hipertensi antara suku Jawa dan suku Madura dengan umur, jenis kelamin, riwayat hipertensi keluarga, aktivitas fisik, kebiasaan merokok, dan status obesitas.

Dalam hal ini di UPT Puskesmas Sigumpar mayoritas suku batak yang memiliki budaya makan Frekuensi makanan yang berisiko hipertensi antara lain makanan pokok seperti nasi, mie instan, makanan lauk hewani seperti daging, ayam, jeroan, ikan, ikan asin, telur juga makanan berpenyedap rasa seperti mie ayam, lontong, bakso, buah dan sayur seperti durian, nangka, sayur daun ubi dan sayur kol serta makanan produk olah seperti es krim, kue dan lainnya. Suku batak adalah masyarakat yang sering berkumpul dan mengadakan pesta seperti pesta sayur, buah dan bunga, pesta pernikahan, pesta tahunan, pesta meninggal, pesta tugu dan pesta lainnya, yang mewajibkan harus makan daging. Didalam pesta tersebut pasti dihidangkan daging babi serta daun singkong yang dicampur dengan santan.

\section{Kesimpulan}

Berdasarkan penelitian yang telah dilakukan, maka diperoleh kesimpulan adanya pengaruh Riwayat Keluarga dengan kejadian hiperteni di UPT Puskesmas Sigumpar, yang artinya riwayat pada keluarga tertentu akan menyebabkan keluarga tersebut mempunyai risiko terkena hipertensi. Individu dengan orang tua menderita hipertensi mempunyai risiko dua kali lebih besar terkena hipertensi daripada individu yang tidak mempunyai keluarga dengan riwayat hipertensi. Adanya pengaruh Merokok dengan kejadian hiperteni di UPT Puskesmas Sigumpar karena Nikotin yang ada di dalam rokok dapat mempengaruhi tekanan darah seseorang, dapat melalui pembentukan plak aterosklerosis, efek langsung nikotin terhadap pelepasan hormon epinefrin dan norepinefrin, maupun melalui efek CO yang dapat berikatan dengan sel darah merah. Adanya pengaruh Obesitas dengan kejadian hiperteni di UPT Puskesmas Sigumpar karena Obesitas merupakan faktor resiko lain yang turut menentukan terjadinya hipertensi. Semakin besar massa tubuh seseorang maka akan semakin banyak darah yang dibutuhkan untuk menyuplai oksigen dan nutrisi ke otot dan jaringan lain. Adanya pengaruh Pola Makan dengan kejadian hiperteni di UPT Puskesmas Sigumpar dikarenakan gaya hidup yang menyebabkan hipertensi dapat dilihat dari kebiasaan konsumsi makanan/pola makan. Kebiasaan konsumsi makanan adalah rutinitas seseorang mengonsumsi makanan yang dikonsumsi sehari hari. Adanya pengaruh Aktifitas Fisik dengan kejadian hiperteni di UPT Puskesmas Sigumpar karena penyebab utama meningkatnya penyakit PTM terutama di Indonesia adalah gaya hidup yang modern yang minim aktivitas dan gerakan fisik. Adanya pengaruh Etnis dengan kejadian hiperteni di UPT Puskesmas Sigumpar. dimana kelompok etnis memiliki keberagaman pola makan dan kebiasan yang dapat memicu terjadinya hipertensi. 


\section{Referensi}

Andri A, Khoiroh S. (2017). Pengaruh Jus Apel Terhadap Penurunan Tekanan Darah Pada Lansia Hipertensi Di Puskesmas Muara Kaman.

Azizah Nur.F. (2013). Aspek Sosial Mempengaruhi Kesehatan. Http://Www. FaktorSosial-Dan-Budaya-Pada-Perilaku.Html.

Cahyono T. (2018). Statistika Terapan \& Indikator Kesehatan. Deepublish.

Hr Hsc. (2018). Metodologi Penelitian Kesehatan Dan Pendidikan. Penebar Media Pustaka.

Kuswardhani T. (2006). Penatalaksanaan Hipertensi Pada Lanjut Usia. J Penyakit Dalam. 7(2): $135-40$.

Novalinda C, Lister Ine, Girsang E, Ginting Jb. (2020). Daun Karet Malaysia Manfaat Untuk Kesehatan. Publ Buku Unpri Press.

Pamuji Lin. (2021). Faktor Risiko Hipertensi Di Kalangan Mahasiswa Diera Pandemi.

Pramuaji Ka, Loekmono L. (2018). Uji Validitas Dan Reliabilitas Alat Ukur Penelitian: Quesionnaire Emphaty. J Ilm Bimbing Konseling Undiksha. 9(2):74-8.

Rakhmah Sa. (2018). Potensi Interaksi Obat Pada Pasien Hipertensi Di Instalasi Rawat Jalan Rsud Dr. Soegiri Lamongan Periode Tahun 2017. Universitas Islam Negeri Maulana Malik Ibrahim.

Ramadhayanti A. (2019). Aplikasi Spss Untuk Penelitian Dan Riset Pasar. Elex Media Komputindo.

Risty D. (2020). Pengaruh Rebusan Daun Sirsak Terhadap Penurunan Tekanan Darah Pada Lansia Hipertensi Di Wilayah Kerja Puskesmas Cipaku Desa Mekarsari Kabupaten Ciamis.

Santoso Ah, Novendy N, Lontoh So. Pelatihan Dan Edukasi Pola Hidup Sehat Dalam Pencegahan Hipertensi Warga Di Sekitar Jakarta Barat Melalui Senam Dan Pengukuran Tekanan Darah. J Bakti Masy Indones. 3(2).

Santoso S. (2020). Panduan Lengkap Spss 26. Elex Media Komputindo.

Tjekyan Rms, Zulkarnain M. (2017). Faktor-Faktor Risiko Dan Angka Kejadian Hipertensi Pada Penduduk Palembang. J Ilmu Kesehat Masy.8(3):180-91.

Wahyudi Ct, Ratnawati D, Made Sa. (2018). Pengaruh Demografi, Psikososial, Dan Lama Menderita Hipertensi Primer Terhadap Kepatuhan Minum Obat Antihipertensi. J Jkft. 2(2):14-28. Nurchoyin M. Kadar Garam Masakan Rumah Dan Profil Tekanan Darah Ibu Rumah Tangga Di Ciputat Timur. 